\title{
Frequency of Babesia vogeli in domestic dogs in the metropolitan area of Piura, Peru
}

\author{
Luis Cerro Temoche ${ }^{1}$, Renata Assad ${ }^{1}$, Eloy S. Seabra-Junior ${ }^{2}$, \\ Tatiana Didonet Lemos ${ }^{3}$, Nadia Almosny ${ }^{2}$
}

\author{
${ }^{1}$ Universidade Federal Fluminense (UFF), Veterinary School, Postgraduate Veterinary Medicine Program, \\ Niterói, RJ, Brazil \\ ${ }^{2}$ Universidade Federal Fluminense (UFF), Department of Pathology and Veterinary Clinical Medicine, Niterói, \\ RJ, Brazil \\ ${ }^{3}$ Centro Universitário Serra dos Orgãos (UNIFESO), Health Sciences Center, Teresópolis, RJ, Brazil
}

Received February 24, 2017

Accepted May 15, 2018

\begin{abstract}
The aim of this study was to assess the presence of piroplasms in dogs in the metropolitan region of the city of Piura, Peru. Two hundred and twelve canine blood samples were randomly collected. The deoxyribonucleic acid was extracted from each blood sample and was tested using the polymerase chain reaction, restriction fragment length polymorphism and sequence analyses. The study showed the occurrence of Babesia vogeli. For the first time, this approach revealed the presence of canine babesiosis caused by $B$. vogeli in Peru. This highlights the need to test for pathogens that might be responsible for causing canine babesiosis, through using proper molecular tools.
\end{abstract}

Piroplasmids, PCR, RFLP, sequence analyses, Latin America

Piroplasmosis is an important tick-borne protozoal disease worldwide, caused by intraerythrocytic protozoa of the genera Babesia and Theileria (Vannier and Krause 2012). The clinical disease in dogs is variable, and the haemolytic type of babesiosis may range from subclinical to severe and fatal (Yamane et al. 1993; Lobetti 1998). The severity of clinical signs, mostly nonspecific, varies with the species or subspecies of Babesia, along with age, host immune response and presence of concomitant infections (Schetters et al. 1997; Boozer and Macintire 2003). The large Babesia spp., previously considered to be B. canis, currently include B. canis, Babesia rossi and Babesia vogeli as distinct species (Solano-Gallego et al. 2016).

Furthermore, there are other piroplasms, apart from B. canis and B. gibsoni, which infect dogs: Theileria annae (Zahler et al. 2000) reclassified as Babesia vulpes (Baneth et al. 2015), B. conradae (Kjemtrup and Conrad 2006), a new species of Babesia, described in North Carolina, USA, named Babesia sp. (coco) (Birkenheuer et al. 2004) and Rangelia vitalii infecting dogs of rural and urban fringe areas (Lemos et al. 2017)

The geographical distribution of piroplasm species is directly related to the distribution of their tick vectors (Sollano-Gallego et al. 2008). In dogs, Rhipicephalus sanguineus is the primary vector of $B$. vogeli; Dermacentor reticulatus is the vector of B. canis; and Haemaphysalis elliptica is the vector of $B$. rossi (Uilenberg et al. 1989). Moreover, $B$. vogeli has an extensive geographical range, considering that many reports have described its presence around the world (Uilenberg et al. 1989; Duh et al. 2004; Gülanber et al. 2006; Criado-Fornelio et al. 2007; Cardoso et al. 2008; M'Ghirbi and Bouattour 2008; Sollano-Gallego et al. 2008; Beck et al. 2009; Hamel et al. 2009).

In South America, Passos et al. (2005) reported B. vogeli for the first time in Brazil through molecular methods, and Sá et al. (2006) did the first report in Rio de Janeiro. The protozoan B. vogeli has also been reported in other South American countries: in Venezuela it was first amplified through molecular analyses in dogs by Criado-Fornelio et al.

Address for correspondence:

MV. Mgr. Luis Fernando Cerro Temoche.

Department of Pathology and Veterinary Clinical Medicine

Faculty of Veterinary Medicine, Universidade Federal Fluminense

Rua Vital Brazil Filho, 64 - Santa Rosa, 24230-340, Niterói, RJ, Brazil

Phone: + 5521990906398

E-mail: luis cerro@hotmail.com

http://actavet.vfu.cz/ 
(2007); in Argentina it was described by Eiras et al. (2008); and in Colombia, the DNA of this haemoparasite was detected by Vargas-Hernández et al. (2012). More recently, in southern Brazil, Trapp et al. (2006) reported B. gibsoni for the first time in South America and confirmed the report with PCR.

In the state of Rio Grande do Sul, Brazil, Loretti and Barros (2005) used immunohistochemical techniques to detect the piroplasm Rangelia vitalii in dogs. In the southeast region, Lemos et al. (2012) were the pioneers in the molecular detection of Rangelia vitalii by PCR and RFLP, and confirming diagnosis with sequencing. Some years later, this protozoan was detected for the first time in dogs in Argentina (Eiras et al. 2014) and Uruguay (Soares et al. 2015).

The Peruvian coastal zone is characterized by arid areas. However, the cold Humboldt marine current provides the central zone of the coast, in the Piura area, with a climate consisting of an average temperature of $31.2^{\circ} \mathrm{C}$ (maximum) and $17.7{ }^{\circ} \mathrm{C}$ (minimum), with $83 \%$ air humidity in the mornings and $51 \%$ at night (Senamhi 2011).

In Peru, ticks that are competent vectors of B. canis and B. gibsoni including Rhipicephalus sanguineus, are highly prevalent (Estares et al. 1999). However, there are no reports describing the presence of these two piroplasms in Peru.

Therefore, the aim of this study was to detect and characterize piroplasm species in dogs in northern Peru using molecular biology methods, such as the polymerase chain reaction (PCR), restriction fragment length polymorphism (RFLP), and sequence analyses.

\section{Materials and Methods}

A survey was conducted in the metropolitan region of Piura, Peru (4'59' 24. 00" S and $\left.80^{\circ} 24^{\prime} 36.00^{\prime \prime} \mathrm{W}\right)$, in which two hundred and twelve canine blood samples were collected from dogs in different urban neighborhoods of this region. The selection criteria did not take age, sex, breed or clinical status into account. The animals' owners were asked to sign an informed consent form prior to data collection. All procedures were approved by the Ethics Committee for Animal Use (CEUA) of the Universidade Federal Fluminense, under protocol 759.

The DNA was extracted from $300 \mu \mathrm{l}$ of whole blood from each sample using a commercially available kit (Illustra Blood Genomic Prep Mini Spin Kit, GE Healthcare, Chalfont St. Giles, UK), in accordance with the manufacturer's instructions. For DNA detection, we used the primers PIRO A (5'-AAT ACC CAA TCC TGA CAC AGG G-3 ') and PIRO B (5'-TTA AAT ACG AAT GCC CCC AAC-3') to amplify a fragment of $400 \mathrm{bp}$ of the $18 \mathrm{~S}$ rRNA gene, which is present in almost all species of piroplasms (Carret et al. 1999). The final concentrations of the reagents involved were $200 \mu \mathrm{M}$ of each dNTP, $200 \mathrm{nM}$ of each primer, $1.625 \mathrm{mM}$ of $\mathrm{MgCl}_{2}, 1.25 \mathrm{U}$ of GoTaq ${ }^{\circledR}$ Flexi DNA Polymerase (Promega ${ }^{\circledR}$, Madison, WI, USA) and $5 \mu$ of the DNA sample, in a total of $25 \mu \mathrm{l}$. The amplification program started with an initial denaturation at $94{ }^{\circ} \mathrm{C}$ for $5 \mathrm{~min}$, followed by 30 cycles of denaturation at $94{ }^{\circ} \mathrm{C}$ for $1 \mathrm{~min}$, annealing at $55{ }^{\circ} \mathrm{C}$ for 1 min and extension at $72{ }^{\circ} \mathrm{C}$ for $1 \mathrm{~min}$. After this, a final extension step was applied for $5 \mathrm{~min}$ at $72{ }^{\circ} \mathrm{C}$ (Carret et al. 1999).

Samples that tested positive for piroplasmids by PCR were then evaluated by means of the RFLP technique, to differentiate Babesia canis, Babesia rossi and Babesia vogeli by means of enzymatic cleavage with Hinf I and Taq $\alpha$ I (Biolabs ${ }^{\circledR}$, New England, USA) at specific sites depending on the species (Carret et al. 1999). The reaction was performed with $10 \mu \mathrm{l}$ of amplified PCR products along with 10 units $(1 \mu \mathrm{l})$ of Hinf I and 10 units $(1 \mu \mathrm{l})$ of Taq $\alpha$ I, and their respective buffers, in different reaction tubes, thus resulting in a $20 \mu$ volume of final solution. Enzymatic digestion was performed in a programmable thermocycler (Applied Biosystems ${ }^{\circledR} ;$ Veriti $^{\circledR}$ ), Foster City, CA, USA) at $65^{\circ} \mathrm{C}$ with the enzyme Taq I, and in a "dry block" (Solab SL20 ${ }^{\circledR}$, Piracicaba, SP, BRA) at $37^{\circ} \mathrm{C}$ for digestion with the enzyme Hinf I, both for one hour.

The PCR and enzymatic restriction products were tested by means of electrophoresis on 1 and $2 \%$ agarose gel, respectively. Both of them were stained with $5 \mu 1 \mathrm{Gel} \mathrm{Red}^{\circledR}$ (Biotium, Hayward, CA, USA) to evaluate the DNA fragment sizes obtained.

To confirm the validity of our PCR results, samples positive for B. vogeli and Rangelia vitalii were used as positive controls. For the negative control, distilled water (UltraPure ${ }^{\mathrm{TM}}$ DNase/RNase-Free, Gibco/Invitrogen, Carlsbad, USA) was used instead of the target DNA. Furthermore, and to ensure that the negative results were reliable, all the samples were tested for the presence of amplifiable DNA through using the primer set GAPDH - F (5'- CCTTCATTGACCTCAACTACAT - 3') and GAPDH - R (5'- CCAAAGTTGTCATGGATGACC - 3'). This provided amplification of a 399-base pair fragment of the gene encoding the glyceraldehyde-3-phosphate dehydrogenase (GAPDH) enzyme, which is present in all mammals (Birkenheim et al. 2003). 
The PCR products of the expected amplicon size (PIRO A/PIRO B) were purified using the illustra GFX PCR DNA and Gel Band Purification Kit (GE Heathcare Life Sciences, Buckinghamshire, UK), in accordance with the manufacturer's instructions, and then were sequenced using Big Dye Terminator Cycle Sequencing Standard Version 3.1 (Life Technologies, Carlsbad, CA, USA) com polymer POP7, in accordance with the manufacturer's instructions, in the sequencer 3130/3130X/Genetic Analyzer Applied Biosystems (Hitachi, USA). The sequences were aligned using the ClustalW software, version 2.1 (Larkin 2007), and the alignment gaps were removed. Subsequently, phylogenetic analysis was performed through the Phylogeny Inference Package (PHYLIP) (Felsenstein 2005), using maximum parsimony analysis with 1000 bootstraps, and a consensus tree was generated (the software applied was Seqboot, Dnapars and Consense). The graphical processing of the tree was performed using the Mega software, version 6.06.

The sequences used in the comparison were Babesia rossi (GenBank accession number L19079), Babesia canis (AY072926) dog-Croatia, Babesia sp. (AY077719) dog-Japan, Babesia vogeli (AY072925) dog-France. These were chosen because they group on the same side of $B$. vogeli in the phylogeny proposed by Lack et al. (2012). Furthermore, the sequences Babesia gibsoni (AF205636) dog-Oklahoma, and Babesia sp. Coco (AY618928) dog-North Carolina were used as comparisons for other species of piroplasms. Likewise, for comparison purposes, we used sequences that have been reported in different places in South America: Babesia vogeli (DQ297390) dog-Venezuela (Criado-Fornelio et al. 2007); Babesia vogeli (EU362993) dog-Argentina (Eiras et al. 1998); Babesia vogeli (KT333456) dog-Brazil (Moraes et al. 2015); and Babesia vogeli (JN368081) dog-Colombia (Vargas-Hernandéz et al. 2012). The sequence Neospora caninum (L24380) was chosen as an outgroup because it belongs to a clade that differs from the Babesia species evaluated (Fig. 1). The sequences of this study were uploaded to Gen Bank and received the following access codes: KY349101, KY349102, and KY349103.

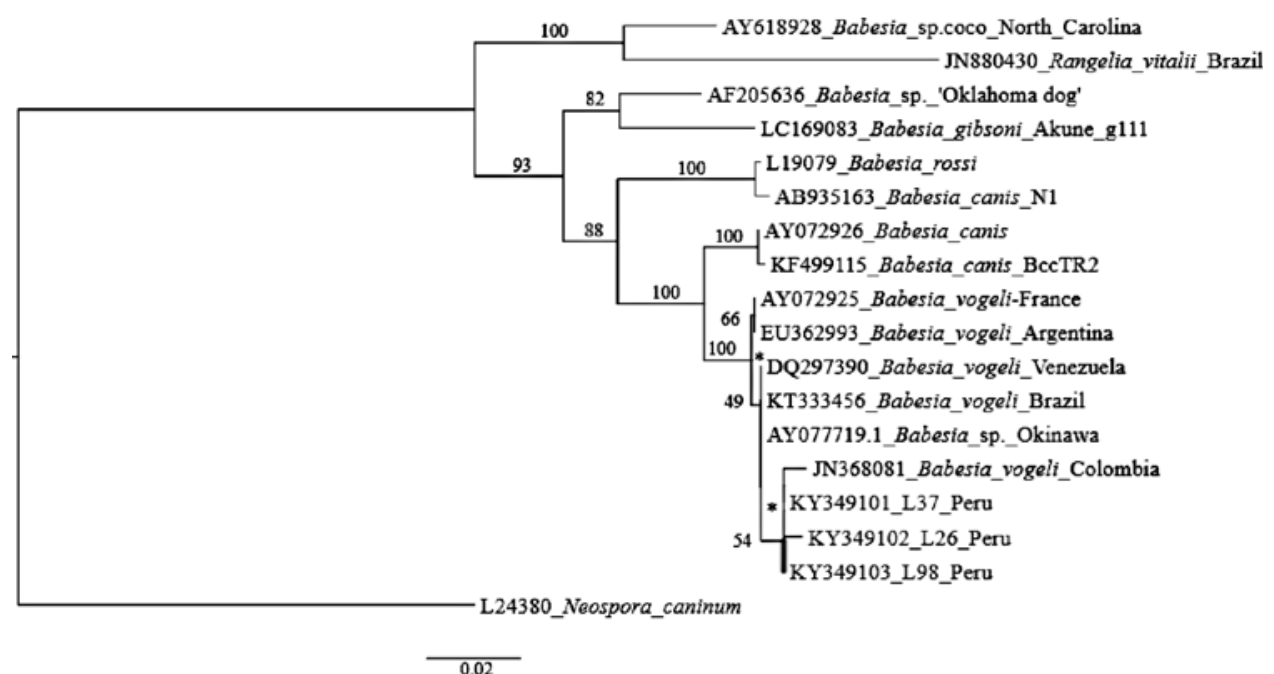

Fig. 1. Phylogenetic tree based on partial sequence of the 18S rRNA gene from samples positive for B. vogeli, in the metropolitan region of Piura, Peru, and related sequences obtained from the GenBank, showing the bootstrap values obtained after 1000 replications. The sequences labelled as "Peru" are samples from this study positive for B. vogeli on PCR-RFLP, namely L37_Peru, L26_Peru, L98_Peru (The sequences of this study uploaded to GenBank). The tree was produced by the PHYLIP's PhyML algorithm using JC69 substitution model. Sequence names are preceded by Genebank IDs and 0 length branches are marked with *.

\section{Results}

All 212 samples were tested with the GAPDH-F and GAPDH-R oligonucleotides. We obtained $400 \mathrm{bp}$ bands indicating the presence of mammalian DNA in the samples. Among the 212 dogs evaluated in the city of Piura, Peru, from December 2014 to March 2015, three (1.4\%) were positive for Babesia sp. By using PCR with the primers PIRO A and PIRO B, the bands were viewed at approximately $400 \mathrm{bp}$. 
The positive samples were exposed to restriction enzyme digestion (RFLP). Use of the Hinf I enzyme did not produce any cleavage, and the only fragment visible was approximately $400 \mathrm{bp}$. The use of the Taq I enzyme produced cleavage in all samples, into two visible fragments: one of $175 \mathrm{bp}$ and $210 \mathrm{bp}$. The cleavage pattern of these samples was compatible with $B$. vogeli (Carret et al. 1999).

\section{Discussion}

This was the first report of Babesia vogeli infecting dogs in Peru, with data obtained through the use of PCR, RFLP, and sequencing. Babesia vogeli was the only species diagnosed in naturally infected dogs in different urban neighborhoods in the metropolitan region of Piura, Province of Piura, Peru, between December 2014 and March 2015.

Compared with positive sample sequences of $B$. vogeli from studies conducted in other regions of Latin America, the samples L26 Peru and L98 Peru showed 99\% identity to EU362993 Babesia vogeli Argentina (370bp), JN368081 Babesia vogeli Colombia (411bp), KT333456 Babesia vogeli Brazil and DQ297390 Babesia vogeli Venezuela. In addition, they demonstrated $99 \%$ identity to positive sample sequences of B. vogeli from studies conducted on other continents: AY072925 Babesia vogeli France and AY0777191 Babesia vogeli Okinawa.

Compared with other piroplasm species, the L98 Peru, L26 Peru and L37 Peru sequences possessed 95, 95 and 93\% identity to AY072926 B. canis Croatia and KF499115 Babesia canis Turkey. Compared with Babesia sp. Coco isolated in North Carolina, USA (AY618928), the L98 Peru, L26 Peru and L37 Peru sequences possessed 89, 89 and 90\% similarity, respectively.

In South America, molecular studies determined the presence of B. vogeli, B. gibsoni and Rangelia vitalii, as aetiological agents for canine piroplasmosis. In Venezuela and Colombia, studies on naturally infected dogs reported that the prevalence of Babesia infection was 2.24\% (3/134) and 5.4\% (5/91), respectively, (Criado-Fornelio et al. 2007; Vargas-Hernández et al. 2012), whereas Eiras et al. (2008) reported the first molecular evidence of $B$. vogeli in Argentina. In the state of Rio de Janeiro, Brazil, Lemos et al. (2012), found 6.8\% (7/103) of positive dogs for Babesia spp by $18 \mathrm{~S}$ rRNA genebased PCR assay.

The three $B$. vogeli-positive dogs described in the present study did not show any clinical signs compatible with canine babesiosis. It must be noted that many "carrier" dogs with chronic infections would not present any clinical signs unless their immune system is compromised. Solano-Gallego et al. (2016) suggested that the presence of clinical signs for babesiosis could be attributed to a weak immune system in chronic infected "carrier" dogs. Similar observations have also been reported in adult Greyhounds and Pit Bull Terriers, which were clinically healthy despite being seropositive for $B$. vogeli and B. gibsoni, respectively. (Taboada et al. 1992; Birkenheuer et al. 2003; Taboada and Lobetti 2006). In general chronic infections result from the inability of the host's immune system to eliminate infection. Pathogens establish themselves and can reproduce with more intensity causing clinical signs when the immune system is debilitated (Solano-Gallego and Baneth 2011).

However, other studies with larger numbers of animals need to be conducted to confirm whether this is the only species of piroplasm that parasitizes dogs in this region at this moment.

\section{Acknowledgements}

The authors thank the Brazilian federal funding body Coordenação de Aperfeiçoamento de Pessoal do Ensino Superior (CAPES) and the state funding body Fundação de Amparo à Pesquisa do Estado do Rio de Janeiro (FAPERJ) for awarding fellowships during the period of this study. 


\section{References}

Ayoob AL, Hackner SG, Prittie J 2010: Clinical management of canine babesiosis. J Vet Emerg Crit Care (San Antonio) 20: 77-89

Baneth G, Florin-Christensen M, Cardoso L, Schnittger L 2015: Reclassification of Theileria annae as Babesia vulpes sp. nov. Parasit Vectors 8: 207

Beck R, Vojta L, Mrljak V, Marinculic A, Beck A, Zivicnjak T, Caccio SM 2009: Diversity of Babesia and Theileria species in symptomatic and asymptomatic dogs in Croatia. Int J Parasitol 39: 843-848

Birkenheuer AJ, Levy MG. Breitschwerdt EB 2003: Development and evaluation of a seminested PCR for detection and differentiation of Babesia gibsoni (Asian genotype) and B. canis DNA in canine blood samples. J Clin Microbiol 41: 4172-4177

Birkenheuer AJ, Levy MG, Stebbins M, Poore M, Breitschwerdt E 2003: Serosurvey of antiBabesia antibodies in stray dogs and American pit bull terriers and American stafford shire terriers from North Carolina. J Am Anim Hosp Assoc 39: 551-557

Birkenheuer AJ, Neel J. Ruslander D. Levy MG. Breitschwerdt EB 2004: Detection and molecular characterization of a novel large Babesia species in a dog. Vet Parasitol 124: 151-160

Boozer L, Macintire DK 2003: Canine babesiosis. Veterinary Clinics: Small Animal Practice 33: 885-904

Cardoso L, Costa A, Tuna J, Vieira L, Eyal O, Yisaschar-Mekuzas Y, Baneth G 2008: Babesia canis canis and Babesia canis vogeli infections in dogs from northern Portugal. Vet Parasitol 156:199-204

Carret C, Walas F, Carcy B, Grande N, Précigout E, Moubri K, Schetters TP, Gorenflot A 1999: Babesia canis canis, Babesia canis vogeli, Babesia canis rossi: Differentiation of the three subspecies by a restriction fragmente length polymorphism analysis on amplified small subunit ribosomal RNA genes. J Eukaryot Microbiol 46: 298-303

Criado-Fornelio A, Veleiron CR, Buling A, Barba Carretero JC, Jefferies R, Irwin P 2007: New advances in molecular epizootiology of canine hematic protozoa from Venezuela, Thailand and Spain. Vet Parasitol 144: 261-269

Duh D, Tozon N, Petrovec M, Strasek K, Avsic-Zupanc T 2004: Canine babesiosis in Slovenia: molecular evidence of Babesia canis canis and Babesia canis vogeli. Vet Res 35: 363-368

Eiras DF, Basabe J, Mesplet M, Schnittger L 2008: First molecular characterization of Babesia vogeli in two naturally infected dogs of Buenos Aires, Argentina. Vet Parasitol 157: 294-298

Estares L, Chavez A, Casas E 1999: Prevalence of ectoparasites of Canis familiaris in the two districts of San Juan de Lurigancho, San Martin de Porres, Comas and independence of Lima. Rev Inv Vet Peru 10: 1-9

Felsenstein J 2005: PHYLIP (Phylogeny Inference Package) version 3.6. Distributed by the author. Department of Genome Sciences, University of Washington, Seattle.

Glenny AM, Mendoza UL, Falconi RE 2004: Detección de anticuerpos contra Borrelia burgdorferi e identificación de garrapatas ixodidas en Piura y Amazonas, Perú. Rev Peru Med Exp Salud Publica 20: 23-27

Gülanber A, Gorenflot A, Schetters TP, Carcy B 2006: First molecular diagnosis of Babesia vogeli in domestic dogs from Turkey. Vet Parasitol 139: 224-230

Hamel D, Silaghi C, Knaus M, Visser M, Kusi I, Rapti D, Rehbein S, Pfister K 2009: Detection of Babesia canis subspecies and other arthropod-borne diseases in dogs from Tirana, Albania. Wien Klin Wochenschr 121: 42-45

Kjemtrup AM, Conrad PA 2006: A review of the small canine piroplasms from California: Babesia conradae in the literature. Vet Parasitol 138: 112-117

Lack JB, Reichard MV, Van Den Bussche RA 2012: Phylogeny and evolution of the piroplasmida as inferred from 18S rRNA sequences. Int J Parasitol 42: 353-363

Lemos TD, Cerqueira AMF, Toma HK, Silva AV, Corrêa RGB, Paludo GR, Massard CL, Almosny NRP 2012: Detection and molecular characterization of piroplasms species from naturally infected dogs in southeast Brazil. Rev Bras Parasitol 21: 137-142

Lemos TD, Toma HK, Assad RQ, da Silva AV, Correa RGB, Almosny NRP 2017: Clinical and hematological evaluation of Rangelia vitalii-naturally infected dogs in southeastern Brazil. Rev Bras Parasitol Vet 26: 307-313

Lobetti RG 1998: Canine babesiosis. Comp Cont Educ Pract Vet 20: 418-430

Loretti AP, Barros SS 2005: Hemorrhagic disease in dogs infected with an unclassified intraendothelial piroplasm in southern Brazil. Vet Parasitol 134: 193-213

M'Ghirbi Y and Bouattour A 2008: Detection and molecular characterization of Babesia canis vogeli from naturally infected dogs and Rhipicephalus sanguineus ticks in Tunisia. Vet Parasitol 152: 1-7

Moraes PH, Rufino CP, Baraúna AR, Reis T, Agnol AM, Meneses DC, Aguiar MR, Gonçalves EC 2015: Molecular characterization of Babesia vogeli in dogs from Belém, northern Brazil. Genet Mol Res 14: 16364-16371

O’Dwyer LH, Massard CL 2002: Babesiose em pequenos animais domésticos e como zoonose. In: Almosny NP. Hemoparasitoses em pequenos animaisdomésticos e como zoonoses. $1^{\text {st }}$ edn. Rio de Janeiro. L. F. Livros de Veterinária LTDA pp 57-67 
Passos LMF, Geiger SM, Ribeiro MFB, Pfister K, Zahler-Rinder M 2005: First molecular detection of Babesiavogeli in dogs from Brazil. Vet Parasitol 127: 81-85

Sá AG, Cerqueira AMF, O’Dwyer LH, Macieira DB, Abreu FS, Ferreira RF, Pereira AM, Velho PB, Almosny NRP 2006: Detection and molecular characterization of Babesia canis vogeli from naturally infected Brazilian dogs. Int J Appl Res Vet M 4: 163-168

Schetters TM, Moubri K, Précigout E, Kleuskens J, Scholtes NC, Gorenflot A 1997: Different Babesia canis isolates, different diseases. Parasitology 115: 485-493

Servicio Nacional de Meteorología e Hidrología - PERU. Información del tiempo, clima y agua. [Accessed 14 of July 2015] Available from: <http://www.senamhi.gob.pe/>

Soares JF, Girotto A, Brandão PE, Silva AS, França RT, Lopes STA, Labruna MB 2001: Detection and molecular characterization of a canine piroplasm from Brazil. Vet Parasitol 180: 203-208

Soares JF, Carvalho L, Maya L, Dutra F, Venzal JM, Labruna MB 2015: Molecular detection of Rangelia vitalii in domestic dogs from Uruguay. Vet Parasitol 210: 98-101

Solano-Gallego L, Trotta M, Carli E, Carcy B, Caldin M, Furlanello T 2008: Babesia canis canis and Babesia canis vogeli clinic pathological findings and DNA detection by means of PCR-RFLP in blood from Italian dogs suspected of tick-borne disease. Vet Parasitol 157: 211-221

Solano-Gallego L, Baneth G 2011: Babesiosis in dogs and cats - expanding parasitological and clinical spectra. Vet Parasitol 181: 48-60

Solano-Gallego L, Sainz Á, Roura X, Estrada-Peña A, Miró G 2016: A review of canine babesiosis: the European perspective. Parasit Vectors 9: 336

Taboada J, Harvey JW, Levy MG, Breitschwerdt EB 1992: Seroprevalence of babesiosis in Greyhounds in Florida. J Am Vet Med Assoc 200: 47-50

Taboada J, Lobetti R 2006: Babesiosis. In: Greene CE (Ed.), Infectious Diseases of the Dog and Cat. Saunders Elsevier, Philadelphia, 722 p.

Trapp SM, Messick JB, Vidotto O, Jojima FS, Morais HSA 2006: Babesia gibsoni genotype Asia in dogs from Brazil. Vet Parasitol 141: 177-180

Uilenberg G, Franssen F, Perie NM, Spanjer AA 1989: Three groups of Babesia canis distinguished and a proposal for nomenclature. Vet Q 11: 33-40

Uilenberg G 2006: Babesia-A historical overview. Vet Parasitol 138: 3-10

Vannier E and Krause PJ 2012: Human babesiosis. N Engl J Med 366: 2397-2407

Vargas-Hernández G. André MR, Faria JL, Munhoz TD, Hernandez-Rodriguez M, Machado RZ, Tinucci-Costa M 2012: Molecular and serological detection of Ehrlichia canis and Babesia vogeli in dogs in Colombia. Vet Parasitol 186: 254-260

Yamane I, Conrad PA, Gardner I 1993: Babesia gibsoni infections in dogs. J Protozool Res 3: 111-125

Zahler M, Rinder H, Schein E, Gothe R 2000: Detection of a new pathogenic Babesia microti-like species in dogs. Vet Parasitol 89: 241-248 